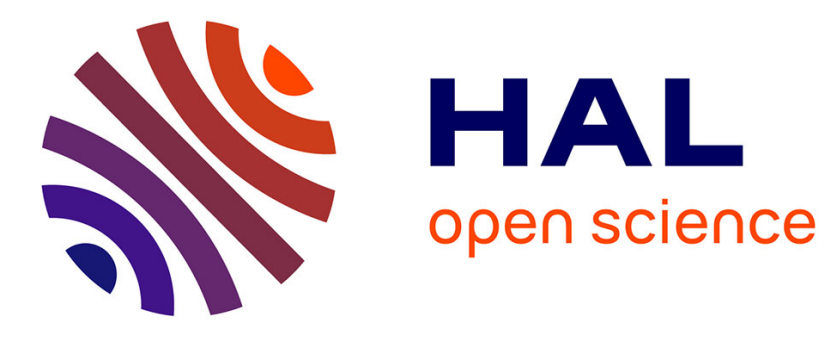

\title{
How do creative genres emerge? The case of the Australian wine industry
}

Grégoire Croidieu, Charles-Clemens Rüling, Amélie Boutinot

\section{To cite this version:}

Grégoire Croidieu, Charles-Clemens Rüling, Amélie Boutinot. How do creative genres emerge? The case of the Australian wine industry. Journal of Business Research, 2016, 69 (7), pp.2334 - 2342. 10.1016/j.jbusres.2015.10.002 . halshs-01498722

\section{HAL Id: halshs-01498722 \\ https://shs.hal.science/halshs-01498722}

Submitted on 30 Mar 2017

HAL is a multi-disciplinary open access archive for the deposit and dissemination of scientific research documents, whether they are published or not. The documents may come from teaching and research institutions in France or abroad, or from public or private research centers.
L'archive ouverte pluridisciplinaire HAL, est destinée au dépôt et à la diffusion de documents scientifiques de niveau recherche, publiés ou non, émanant des établissements d'enseignement et de recherche français ou étrangers, des laboratoires publics ou privés. 


\section{How do creative genres emerge? The case of the Australian wine industry}

Grégoire Croidieu, Grenoble Ecole de Management

Charles-Clemens Rüling, Grenoble Ecole de Management and IREGE, Université Savoie Mont Blanc

Amélie Boutinot, ISG Paris and Grenoble Ecole de Management

Cite as: Croidieu, G., Rüling, C., \& Boutinot, A. 2016. How do creative genres emerge? The case of the Australian wine industry. Journal of Business Research, 69: 2334-2342.

Send correspondence to Grégoire Croidieu, Grenoble Ecole de Management, 12 rue Pierre Sémard, 38000 Grenoble (gregoire.croidieu@ grenoble-em.com); Charles-Clemens Rüling, Grenoble Ecole de Management, 12 rue Pierre Sémard, 38000 Grenoble (charlesclemens.ruling@grenoble-em.com); Amélie Boutinot, Institut Supérieur de Gestion, 147 avenue Victor Hugo, 75116 Paris (amelieboutinot@gmail.com). 
How do creative genres emerge? The case of the Australian wine industry

\begin{abstract}
The present paper examines how a new, creative genre emerges out of a commodity-based industry. Building on the genre-emergence literature, the paper analyzes the Australian wine industry since the 1950s. Based on content analysis of a wide variety of sources, the study identifies four mechanisms that account for creative-genre emergence: shifting and layering of metrics, analogies with established creative industries and practices, resonance with societylevel logics, and personification. The results contribute to the genre-emergence and creativeindustries literatures.
\end{abstract}

Keywords: genre emergence; boundary formation; creative industries; production-ofculture perspective; Australian wine 


\title{
INTRODUCTION: THE EMERGENCE OF A NEW GENRE IN AUSTRALIAN WINE
}

\author{
"A concoction of wild fruits and sundry berries with crushed \\ ants predominating ..., which no one in their right mind will buy \\ - let alone drink." (John Davoren, 1956)
}

Less than 50 years after John Davoren, winemaker at Penfolds, had ridiculed and dismissed Penfolds Grange, a new wine painstakingly created by his colleague Max Schubert, the Australian wine industry had undergone a profound revolution. Higher-quality table wines had replaced cheap fortified wines, with many qualifying as fine wines with exceptional organoleptic (i.e. sensory) qualities and aging potential. Large corporations continued to produce low-price, commodity-style wine for export markets, but were increasingly challenged by new, entrepreneurial ventures that considered winemaking as both a commercial and an esthetic endeavor. In addition, new stakeholders such as wine connoisseurs, journalists and critics, collectors, and auction houses marked the emergence of a new, creative genre within the Australian wine industry in the early 1960s. This paper studies the mechanisms that enabled the emergence of this new, creative genre within an existing commodity-based mass-production industry.

Traditionally, research on genre emergence in the creative industries looks at the formation of new genres from pre-existing ones (e.g., Becker, 1982; Ennis, 1992; Peterson, 1990; Peterson and Anand, 2004). Recent work highlights the role of cognitive boundaries in these processes (Lena, 2012; Lena and Peterson, 2008). However, the question of how a creative genre emerges within a commodity-based industry remains unaddressed. 
The present paper focuses on this issue by tracing the evolution of the Australian wine industry since the 1950s. The paper identifies four mechanisms that drove the process of genre emergence: shifting and layering of metrics, analogies with established creative industries and practices, resonance with society-level logics, and personification.

The study makes four contributions to the genre-emergence and creative-industry literatures: highlighting the cognitive functions of metrics; stressing the role of analogies in creating cohesion around emerging genres; linking factors traditionally associated with genre emergence to society-level dynamics; and discussing the role of personification. The study achieves this last contribution through demonstration that a new genre is not necessarily the outcome of strategic agency, but that creative geniuses may be discursively constructed to consolidate a new genre during the final stage of genre emergence.

\section{THEORETICAL BACKGROUND}

\section{Creative Industries, Genres, and Genre Emergence}

The design, production, and commercialization of esthetic and symbolic content characterize creative industries (Alvarez, Mazza, Strandgaard Pedersen, and Svejenova, 2005), which people regard as being at the forefront of innovation, both in products and services and in management and organizational practices (DiMaggio, 1991; Hirsch, 2000). Understanding how creative activities can develop within commodity-based environments is therefore of interest.

Recent research on genres and genre emergence provides a basis for conceptualizing the development of creative practices within commodity-based industries. In the culturalsociology and creative-industries literature, genres denote "systems of orientation, expectation, and conventions that bind together an industry, performers, critics and fans in making what they identify as a distinctive sort of creative experience" (Lena and Peterson, 2008, p. 698). 
Genre emergence implies cognitive processes that connect disparate actors and audiences around a new, coherent genre, which in turn guides the collective production of symbolic content (Hsu, 2006). Scholars have proposed three interrelated perspectives to explain the emergence and evolution of genres (Anand and Croidieu, in press). First, Becker (1982) emphasizes the role of multiple social actors for understanding the creation and legitimacy of specific art forms. Second, building on Becker's work, Ennis (1992) theorizes genres as "streams," arguing that genre emergence requires both a favorable constellation of actors and changes in the configuration of existing streams of activity. The third perspective, building on the production-of-culture perspective, focuses on "how the symbolic elements of culture are shaped by the systems within which they are created, distributed, evaluated, taught, and preserved" (Peterson and Anand, 2004, p. 311). This approach identifies six factors that interact in shaping genres: technology, law and regulation, industry structure, organization structures, occupational careers, and markets. Recent empirical studies build on this perspective to study trajectories of genres within creative industries (Lena and Peterson, 2008).

\section{Genre Emergence: Commensuration, Authenticity, Status Ordering, and}

\section{Comprehensibility}

The emergence and evolution of genres require the formation of boundaries (Lena and Peterson, 2008). Boundary formation is a set of processes resulting in the creation, maintenance, and disappearance of social and cognitive boundaries, and underlying a variety of phenomena, including the dynamics of collective identity, professions, or communities (Lamont and Molnar, 2002), as well as the emergence and development of esthetic boundaries (Pachucki, Pendergrass, and Lamont, 2007). 
The literature on genre emergence suggests four interrelated problems that play a critical role in boundary formation: commensuration, authenticity, status ordering, and comprehensibility.

Commensuration refers to the problem of comparability between different genres within an industry. A new genre must differentiate itself from pre-existing ones, and audiences need common metrics to evaluate this difference. Commensuration is of critical importance for valuation processes in fields (Espeland and Stevens, 1998; Karpik, 2007; Khaire and Wadhwani, 2010).

Authenticity is the extent to which the members of a genre conform to most of the rules of a genre most of the time (Peterson, 2005). Whereas commensuration allows comparing across genres, authenticity here refers to the internal coherence of a genre in the sense of "type authenticity" (Carroll and Wheaton, 2009). The formation of a genre is characterized by the simultaneity of conformity ("most of the rules, most of the time") and differentiation within the emerging rules of the genre (Beverland, 2006). If either conformity or differentiation is lacking, the new genre does not form, or audiences will reject members perceived as inauthentic (Carroll and Swaminathan, 2000).

Status ordering allows distinction between members of a genre by shaping the attention of audiences (Anand and Peterson, 2000). Without status ordering, a new genre is unlikely to emerge because audiences are unable to perceive the internal structuration.

Finally, comprehensibility refers to the extent to which people define and understand a genre on the basis of a clear and coherent account. Following Suchman (1985, p. 582), comprehensibility refers to the availability of cultural models to supply plausible explanations and content. These explanations and this content establish legitimacy across audiences and play an important role in enabling audiences to make sense of a new genre. 
To summarize, the emergence of a creative genre within a commodity-based industry faces the four interrelated problems of commensuration, authenticity, status ordering, and comprehensibility. The concrete mechanisms and processes by which these problems cease to cause difficulties in the formation of a new, creative genre is the focus of the empirical study, which addresses the following overall research question: How do creative industries emerge in the context of commodity-based industries?

\section{RESEARCH DESIGN AND METHODS}

The evolution of the Australian Wine industry since the 1950s serves as a revelatory case to identify the mechanisms that drive creative-genre emergence. This case is particularly suited to the study of creative-genre emergence in a commodity-based industry, because since the 1960s, Australian wine has witnessed the emergence of a creative fine-wine genre, deviating from its historically established commodity-based logic of mass production. The interplay of local and national-level actors has facilitated the historical redefinition of the

industry, based on strong domestic innovation capacity (Aylward, 2004, 2006; Aylward and Turpin, 2003).

Six different markers characterize the fine-wine genre (Robinson, 2006): use of premiumgrape varieties; distribution in standard bottles; aging capacity of the wines after bottling; visibility at wine shows and auctions; coverage by national and international critics, wine websites, and guidebooks; and significant price premiums. As Table 1 shows, the strong increase in the share of table wine in total Australian wine production (from below $30 \%$ before 1970 to above $90 \%$ after 1990) and the almost-twentyfold rise in premium-grape crush over the last five decades reflects the ongoing emergence of the Australian fine-wine genre over the same period. The establishment of new wineries has exploded since the 1970s, culminating in more than 1,000 new wineries coming into existence between 1990 and 1999 . Over the period that the study examines, wine consumption in Australia increased sixfold, and 
annual wine exports increased from 4 million USD (representing less than $1 \%$ of global wine exports) to more than 1.5 billion USD (representing more than $8 \%$ of global exports).

\section{Table 1 here}

Genre emergence involves multiple actors and audiences on different levels and over extended periods of time. Following prior research (e.g., Peterson, 1990; Peterson and Berger 1975), the study investigates genre emergence at both industry and product levels. The twolevel research design facilitates the identification of key mechanisms at the industry level and a more precise understanding of how they operate at the product level. At the industry level, the study examines genre emergence by documenting the principal evolutions and industry actors in six areas: technology, law and regulation, industry structure, organization structure, occupational careers, and markets (Peterson and Anand, 2004). At the product level, the study looks at the development of one particularly well-documented wine, Grange, which strongly relates to the new genre (e.g., Byron and Ashenfelter 1995). The study includes this wine to illustrate the mechanisms of genre emergence at the micro level. Penfolds, a large Australian wine producer, has produced Grange since the early 1950s. One of the company's winemakers, Max Schubert, created the wine in 1951, after an opportunity to taste very old French Bordeaux wines, when he became determined to match such wines' quality and aging potential. After its growing recognition in Australia since the 1960s, Grange received strong international acclaim from the 1980s, culminating in its 1995 nomination as wine of the year by the renowned U.S. magazine Wine Spectator.

Data sources at the industry level comprise texts covering a wide range of actors and audiences, including general and specialist media, wine critics, wine shows, auction houses, collectors, and the winemaking profession - as well as academic articles and books on wine 
marketing, economics and technology; industry reports; official statistics; and historical accounts of the Australian wine industry. In addition, the data include quantitative and qualitative data from professional organizations (Australian Society for Viticulture and Oenology, Australian Wine Research Institute, and Australian Wine Board) and a training institution (University of Adelaide). Price and market data come from the two main generalist auction houses in Australia, and from the leading specialized wine-auction house, which publishes a highly regarded classification of Australian premium fine wine. Additional data come from the main Australian wine-show organizations as well as from books; encyclopedias; consumer guides; and wine ratings by Australian, British, and American critics.

At the product level, the research uses a database comprising texts about Grange from various sources over time, following the principles of archival research (Ventresca and Mohr, 2002) to study the dynamics of meaning associated with boundary formation. The database includes 383 English language press articles retrieved from Factiva and Lexis-Nexis electronic archives, from the National Library of Australia's online database, and from the electronic archive of The Sydney Morning Herald, the oldest and most reputed Australian newspaper. In addition, the database comprised a complete set of texts printed on Grange bottle labels since 1952, together with other corporate publications, in order to trace the producer's discourse. Further documents include Hooke's (1994) extensive biography of Grange winemaker Max Schubert, as well as a series of statements about Grange from wine judges and professionals.

The researchers content-analyzed and coded all press articles using NVivo 9.0 qualitativedata-analysis software. The first-order codes were descriptive and remained close to the data. The analysis proceeded with a search for relationships and interactions among the first-order codes to identify the mechanisms underlying genre emergence. By confronting product-level 
observations with industry-level data, the analysis yielded ten more abstract second-order themes (see Table 2 for illustrative quotes), which the researchers regrouped into four overarching analytic dimensions (see Figure 1 for an overview of the data structure), representing four mechanisms (see the next section).

Table 2 here

Figure 1 here

\section{FINDINGS: MECHANISMS OF GENRE EMERGENCE}

The data analysis yields four mechanisms accounting for the development over time of the new, creative genre in Australian wine. Beginning in the 1950s, shifting and layering of metrics provide the impetus for the emergence of the new fine-wine genre. In the 1970s, the new metrics lead to a second mechanism involving analogies with creative industries and practices. Subsequently, in the late 1970s, a third mechanism based on the resonance of the new genre with society-level logics comes into play. The fourth mechanism, personification, occurs since the late 1980s and involves the construction of creative authorship. This section presents the four mechanisms one by one, and the following discussion section shows how the four mechanisms interact over time to shape the boundaries of the new genre.

\section{Shifting and Layering of Metrics}

The first mechanism involves the development and superposition over time of new metrics associated with different actors and audiences such as wine shows, wine critics, and wine auctions. Historically, wine shows play an important role in shaping the Australian wine industry (Dunphy and Lockshin, 1998). During the first half of the $20^{\text {th }}$ century, the primary aim of such shows was to ensure the supply of marketable wines by assessing their sanitary quality. In the early 1960s, the Adelaide wine show was the first to introduce a new 
evaluation based on more precise quality criteria, and the associated systematic training of wine judges put a stronger emphasis on the organoleptic quality of wines. As a consequence, judges assessed even unusual wines such as Grange on the basis of their intrinsic quality rather than just their relation to pre-existing wine styles. In the case of Grange, early wineshow success under the new evaluation criteria proved instrumental in gaining visibility and recognition among wider audiences. In 1962, Penfolds submitted the 1955 Grange to the Royal Sydney Wine Show, and the wine immediately won a gold medal. In the following two decades, Grange received 28 trophies, and 126 gold, 76 silver, and 42 bronze medals (Hooke, 1994, p. 84). Wine-show success was important for wines in order to signal genre membership and gain visibility among fine-wine audiences. In the mid-1970s, for instance, Wolf Blass, an important competitor of Penfolds, used wine-show successes as a foundation of an important marketing campaign.

Following the change of metrics in the wine-show system, the first Australian wine journalists and critics appeared, as did the first regular wine columns in the Australian general-interest press (for instance, since 1967 in The Sydney Morning Herald). Since the early 1970s, wine writers (e.g. James Halliday) began publishing guidebooks on Australian wines, and international wine critics included such wines in their publications, spreading information about the new genre to wine connoisseurs internationally.

In the 1970s, several Australian auction houses began to organize wine auctions, creating price information for older vintages and catering to a growing audience of wine collectors who bought wine not only for immediate consumption but also for constituting their personal collection - and, especially since the 1980s, as a financial investment. Langton's, a specialist Australian wine-auction house, began in 1991 to issue a highly regarded classification of the most outstanding Australian wines. 


\section{Analogies with Established Creative Industries and Practices}

After the establishment of new metrics, various forms of analogies with established creative industries and practices facilitated the interpretation of the new fine-wine genre; these analogies included references to prestigious European fine-wine regions and practices connected to the art world.

At the core of the changes that characterized Australian fine wines was the increase of their aging potential, which entrepreneurial winemakers developed, importing winemaking techniques from already-prestigious wine regions. In the early 1960s, Grange bottle labels, for instance, mention that Grange "in the manner of all the finest Red Table Wines reaches full ripeness only after a long maturation in the bottle" (1961 bottle label). The wine's capacity and need for aging was not only a distinctive characteristic of the most prestigious old-world wines, but also resonated with a shift from immediate drinking to cellaring for future consumption, collection, or investment. Aging provided a topic for wine writers and critics, who could comment on specific wines and vintages over the wines' life span in the bottle, and also allowed collectors to search for highly ranked vintages. This development was in line with the growth of a secondary market, in which auction houses played an increasingly important role in providing price data and in creating expectations about the economic performance of specific wines.

With the growing interest of international wine critics in the 1970s, Australian fine wines needed to position themselves more clearly in relation to the global wine circuit. On the $25^{\text {th }}$ anniversary release of Grange in the late 1970s, Penfolds, for example, introduced a new bottle label, which for the first time emphasized the connection of Grange to the prestigious French Bordeaux region:

"During an extensive tour of the Bordeaux region of France in 1950, Max Schubert studied numerous wine-making practices that have now become an integral part of Penfolds wine- 
making technique. He also observed the practice of maturing wine in new oak casks, a method previously untried in Australia." (1976 bottle label)

The Bordeaux reference on the 1976 Grange label was linked to a strong claim highlighting the "beginning of a new era in Australia's red wine making tradition," and connecting the uncontested prestige of Bordeaux with the idea of creating something new for Australia. In this context, producers' roles evolved to respond to the new needs of buyers and collectors. Numerous wineries began providing background information on their wines, the history and characteristics of their vineyards, the wines' expected development over time, etc. Penfolds, for example, emphasized its custodianship of Grange, and adopted a curator role for its wines in the context of its regular Re-Corking Clinics to assess and certify, in collaboration with prestigious auction houses, the quality and value of bottles older than 15 years. These practices highlight producers' responsibility over time to sustain the value of their wines for collectors, and underscore the difference between fine wines and commodity-type wines produced for rapid consumption.

An additional association with established creative industries occurred in the media, which presented fine-wine connoisseurship and consumption as esthetic experiences. In many instances, the description of fine wines in the media focused not solely on a specific wine, but also on the particular circumstances in which consumption took place, associating the wines with famous places, celebrities, art, or haute cuisine - as, for example, in the case of the Ultimate Dinners jointly organized since 1983 by Penfolds and Hilton. Overall, annual percapita wine consumption in Australia increased from six liters in the 1960s to more than 20 liters after 2000 (see Table 1).

Analogies and associations with established creative industries (e.g. the Bordeaux wines) and practices (e.g. curatorship) helped define the boundaries of the fine-wine genre. Analogies with other prestigious wine regions served as programmatic statements, and actors and 
practices normally associated with the arts-and-culture field (critics, collectors, auctions, etc.) marked a clear difference in relation to everyday consumption.

\section{Resonance with Society-Level Logics}

A third mechanism, which appeared only slightly after the development of creativeindustry analogies, involves resonances with society-level logics. From the late 1970s, various audiences increasingly connected the fine-wine genre with images and narratives relating to the history and identity of Australia, and its national heritage and pride. Wine producers, for example, sought to establish a connection between wine consumption and Australian culture. In particular, the newly established small, entrepreneurial wineries echoed the construction of postcolonial Australian national identity around notions such as simplicity, wholeness, and closeness to a rough natural environment. This imagery was also reminiscent of early Australian winegrowing, which faced a hot, dry climate and unfavorable geographical conditions (Johnson, 1989; Osmond and Anderson, 1998).

Max Schubert, the creator of Grange, for example, took on the image of a "renegade" (Penfolds' advertising, 2007) who set out “to challenge the old order - and win" (Clarke, 2004, p. 22). These images emphasized a positive valuation of courage and strong personal will, resonant with the determination of nation-building. Likewise, the entrepreneurial spirit of the winemakers, the prevalence of strong individuals, and their personalities stood out as specificities of Australian winemaking, setting Australia apart from other countries that "build their reputation on the places where the grapes grow" (Clarke, 2004, p. 30).

The National Trust of Australia, a non-governmental organization created in 1945 to protect and promote the country's natural and historic heritage, officially recognized Grange as a Heritage Icon of South Australia to "be recognized, celebrated and protected for present and future generations" (The Sunday Times, 2001). This example further illustrates the role of society-level logics as symbolic anchors of the fine-wine genre. The new genre's resonance 
with overarching societal discourses established symbolic meaning and a sense of historical necessity, connecting the new wines back to a lost paradise, an imaginary and idealized time before industrial mass-market wine production.

\section{Personification}

After the shift of metrics and the associations of fine wine with other creative domains and fundamental societal discourses, the final mechanism involves personification of the winemaker, emphasizing the individual winemaker's contribution to the evolution of the industry and the fine-wine genre, and highlighting the role of creative authorship for a specific wine.

Personification at the level of specific wines constructs the sense of authorship and suggests that one cannot dissociate a given wine from its creator. This construction of authorship is evident in the example of Grange. Since the 1965 vintage, the bottle labels mention Max Schubert on the bottle labels, and Schubert himself has contributed to the discursive construction of authorship by giving public lectures on the story of Grange, and by personally signing Grange bottles for collectors, who highly value his autograph.

At the industry level, winemakers have, since the 1990s, increasingly taken on a role of being "the public face" (The Age, 1996) of wine-producing firms, forming a lineage over time of individuals entrusted with the knowledge of creating Australia's most prestigious wines. Individual winemakers appeared as symbolic representations, embodying the virtues of their creative genre and providing a role model for other members. A reflection of the growing personification in the wine industry lies, for instance, in the creation of awards such as the Australian Maurice O’Shea Award, established in 1990 to distinguish "historically significant and outstanding contributions to the Australian wine industry" (www.mcwilliamswine.com). At an international level, the UK wine magazine Decanter has, since 1984, nominated a Man 
of the Year, to recognize individuals who have made important contributions to the world of wine.

\section{DISCUSSION AND CONCLUSION}

The four mechanisms that drove genre emergence in the case of Australian fine wine did not occur independently from one another, but are connected and interact in the overall process (see Figure 2 for a graphical representation): The emergence of the new genre began with the creation and layering over time of new metrics and evaluation instances. The new metrics and valuation instances drew analogies between the new genre and existing creative fields. Wine critics established connections with international fine-wine regions, and the development of wine auctions later facilitated analogies to the art world. In parallel, the growing international exposure at the level of metrics and valuation facilitated the gradual development of references to the new genre that were resonant with a specific understanding of Australian national identity. Finally, the new, creative genre came to fruition through personification, a mechanism that aligned equally with personal awards as the most recent layer of valuation, with the dominant image of the artist-creator as an analogy in the arts-andculture field, and the memory of bush farmers and early wine growers in Australian agricultural history.

Figure 2 here

The following sections discuss how the interaction of the four empirical mechanisms over time facilitated the formation of the new fine-wine genre by solving the four problems of commensuration, authenticity, status ordering, and comprehensibility. Table 3 summarizes how the empirical mechanisms map onto four theoretical problems associated with genre formation. 
Table 3 here

\section{Commensuration}

Commensuration allows the "comparison of different entities according to a common metric" (Espeland and Stevens, 1998, p. 313). In this case, two mechanisms were central in enabling commensuration, namely the shifting and layering of metrics, and the analogies with established creative industries and practices. During the first stage, the establishment of auction prices as a common metric linking wine to other art and luxury or investment items allowed collectors, artists, brokers, and investors to connect in comparing different creative products. Similarly, international wine ratings such as the 100-point scale popularized by U.S. critic Robert Parker enabled the direct comparison of the new Australian wines with firmly established European fine wines.

During the second stage, the various analogies with established creative industries and practices drove commensuration. As important cognitive mechanisms, analogies are often central to the foundation of institutions (Douglas, 1986). In a recent study, Etzion and Ferraro (2010) confirm the legitimizing effect of analogies, but also show the extent to which analogies provide a basis for differentiation and creativity by focusing attention on incongruences of the target with its analogical source. In the case of fine wines, analogies complemented metrics as cognitive devices enabling the comparison of industries that were cognitively distant. Analogies between wine and art, for example, played a key role in establishing wine as a cultural product and wine consumption as an esthetic experience. More importantly, they provided cultural-cognitive templates defining how wine should be compared and evaluated, thus creating an entry point for collectors, auction houses, and investors familiar with other creative industries, products, and practices. 


\section{Authenticity}

Authenticity increases the coherence of a genre and the differentiation of its members. By establishing coherence, authenticity connects audiences and producers to a genre. By enabling (and sometimes even requiring) differentiation, authenticity fosters the creative and esthetic evolution of a genre. Two mechanisms in this study contribute to establishing authenticity in relation to the new genre: the layering of metrics and instances of valuation; and the personification process.

First, the coexistence of different metrics and valuation instances that develop over time establish coherence within the genre and at the same time allow for creative variation by enabling, for instance, two wines with very different styles to yield similar prices at wine auctions. During a later stage, personification plays an important role in constructing authenticity. Other than in the traditional standard account of genre evolution based on the idea of a creative agent or genius establishing new conventions (e.g., White and White, 1965), the findings of this study suggest that the process of embodying the essence of a new genre in the figure of individual creative geniuses may occur only during the final stages of genre emergence, and may build on other mechanisms, such as, in the present case, layering of metrics, analogies to established genres, and societal resonances. One can reinterpret this observation in the light of Chauvin's (2010) recent work on the emergence of signatures in the Bordeaux wine industry at a point in time when winemaking as a profession achieved recognition.

The present study shows that personification provides an additional spectrum along which members of the new genre could at the same time display conformity (in identifying with the winemaker associated with a prestigious wine) and differentiation (in terms of the variety of individual winemakers' origins, training, experiences, recognition, and personalities). In the 
emergence of Australian fine wine, however, personification provides the necessary final step in the process of genre emergence, instead of constituting its foundation.

\section{Ordering}

Ordering involves the classification and struggle between genre members seeking to distinguish themselves (Bourdieu, 1984). Status orders play a key role in genre emergence; they function as a magnet binding actors to a given genre (Anand and Peterson, 2000). In the case of Australian wine, metrics and instances of valuation play a key role in ordering the genre, acting both as a stabilizing mechanism and as a mechanism of change. As stabilizing mechanisms, metrics have established and reproduced a status hierarchy, and have facilitated genre emergence by providing a sense of coherence and structuration. For instance, the six wine classifications issued since 1991 by Langton's, Australia's leading wine-auction house, have established a relatively stable status hierarchy among the leading fine wines.

The development of new layers of metrics, on the other hand, provides opportunities to create competing prestige scales and/or to question established status orders. The wine-show system initially established the value of fine wine in terms of intrinsic product quality. When international wine writers arrived, they defined value also in reference to established finewine styles, mainly in Bordeaux and other prestigious French wine regions, while the development of auction houses introduced investment value as an additional criterion. With the development of international critics and wine ratings in the 1980s, a new value scale emerged, emphasizing the value of being distinctively Australian, whereas personification connected the value of a specific fine wine to the prestige of the winemaker as a creative artist.

These observations complement prior studies on genre emergence (Anand and Peterson, 2000) by highlighting how the change of metrics over time contributes to reinforcing the stability of a genre; facilitates - via sequential redefinitions - the connection of additional 
audiences to an emerging genre; and provides genre members with opportunities for signaling genre membership (Lampel and Shamsie, 2000). Whereas research most often interprets metrics as sources of monetary and non-monetary incentives that orient actors' choices, the present study highlights the essential cognitive function of layered metrics in connecting different audiences.

\section{Comprehensibility}

As the theory section outlines, the emergence of a new, creative genre within a commodity-based industry must address the issue of comprehensibility. In other words, different audiences need to understand a new, creative genre as coherent. In the case of Australian fine wine, three interacting mechanisms established comprehensibility: Initially, metrics and instances of valuation played a key role in establishing how people would understand and categorize the first (and, at the time, deviant) wines. Later, as the wines forming the foundation of the new genre differentiated themselves by their wine-show successes, analogies with established fine-wine regions and with other creative industries became critical in conveying a sense that understanding of the new wine genre must take place in the light of well-accepted creative industries. In parallel, comprehensibility of the new genre to the wider Australian public (including both policy makers and new groups of consumers) became possible through resonance with overarching societal logics, a mechanism that "captures and activates powerful distinctions along social, ethnic, religious, economic, political, and cultural lines" (Baron, 2004, p. 11). Whereas the earlier literature called for connecting genre emergence with broader societal dynamics (Peterson and Anand, 2004), the present research findings explicitly highlight the legitimating role played by resonances with broader societal logics.

\section{The Role of Agency in Genre Emergence}


The production-of-culture perspective emphasizes the role of structural and cultural configurations for genre emergence. Other work on creative industries stresses agency as the main driver of genre emergence, as in the case of nouvelle cuisine (Rao, Monin, and Durand, 2003). The results presented above contribute to enriching this conversation in two ways: First, unlike in purely commodity-based industries, (symbolic) value in creative industries lies to a stronger extent in the eyes of external audiences who bestow recognition. In this case, agency is not so much about managing and controlling resource dependences, but about interacting and finding an appropriate position within a network of audiences. In the case of the Australian wine industry, these audiences (critics, auction houses, collectors, etc.) were not present until the late 1970s. They have coevolved with the new genre and achieved full alignment in the 1990s along the boundary-formation processes discussed above. As Table 1 suggests, the new genre hardly diffuses as long as these audiences are not in place, whereas both the value of wine exported and the number of entrepreneurial firms promoting the new genre rise exponentially as the audiences and boundaries of the new genre fall into place in the 1990s. At the product level, a shift occurs from considering an old bottle as a potentially perished beverage toward seeing such a bottle as a collectible luxury item. Once the secondary market involving auction houses and collectors develops, old wines become tradable goods. Moreover, competitors appropriate the values, discourses, and metrics of those audiences and strategize based on them. Signaling (Lampel and Shamsie, 2000) provides a good illustration of these strategies, as wine producers display wine reviews on their websites, print medals and awards on wine labels, and adorn their premises with trophies and distinctions. Finally, agency can also take the form of voluntary actions led by powerful and central (regulative and normative standard-setters) actors (e.g. trade associations) that can have strong influences on shaping new genres - as, for example, in Canadian wine (Tefler, 2001). In Australia, the first and most important industry-wide strategic initiative began in 
1996 (Winemakers' Federation of Australia, 1996). The fact that this form of collective strategizing occurred very late in the process reinforces the hypothesis that structural and cultural factors precede more deliberate agency. Further, a look at the content of these strategic initiatives reveals that most actions concern the creation of structures aiming at facilitating production or export, which further reinforces the structural conditions behind the emergence of the fine-wine genre. In other words, new-genre emergence involves adaptive and interactive - rather than purely strategic - agency.

Second, as already mentioned above, agency in the form of individual creative action is almost consubstantial to the idea of creative industries. From this viewpoint, individual winemakers as creative geniuses give birth to exceptional wines and play a key reputational role in signaling quality and excellence to audiences (Roberts, Khaire, and Rider, 2011). The present study suggests, on the contrary, that personification may actually occur very late, illuminating the importance of social discourses portraying individual agency and conveying the symbolic value associated with creative industries.

\section{Limitations and Further Research}

As with all empirical studies, this research has limitations. The focus on one pioneering product in this study captures neither the overall evolution of the content of the Australian fine-wine genre nor the degree to which newcomers imitate the pioneers. An extension of the present research to study imitation dynamics within the new genre would further the understanding of genre trajectories (Lena and Peterson, 2008). Second, in an effort to build theory, this study highlights and discusses mechanisms and processes, which should lead to further studies. Concerning the use of analogies, the case of the Australian wine industry calls into question both the ontological status of wine and the effects of the various analogies on genre emergence - establishing wine as a refreshing beverage for some, and as a financial investment or a collectible item for others. Considering, in addition, the mechanism of 
personification and the issue of authenticity, one could wonder what would have happened, had the analogies not originated in high-culture, avant-garde, or other prestigious genres, but in popular culture, craft, or environmental movements. Finally, the activation of national identity challenges the well-entrenched idea of an ongoing struggle between an old world and a new world of wine. On one hand, Grange and its followers highlight their connection to the Bordeaux model and thus reproduce the traditional European cultural predominance in wine. On the other hand, this link also bears a strong competitive aspect, under which the new Australian wines were seen as challengers to the old order. On the basis of these observations, improving the understanding of processes underlying the global diffusion of genres remains an important area for future research.

\section{Final Thoughts}

This study contributes both to building the literature on genre emergence and to understanding the dynamics of creative activities, by identifying and discussing the processes by which a creative genre develops within a commodity-based industry. The Australian wine industry currently faces the problem of vast overcapacities for undifferentiated, entry-level wines, leading to massive uprooting, whereas the Australian fine wines are booming. This observation suggests that the production of symbolic content may, in many cases, also signify a greater appropriation of value by producers, which would be a desirable outcome in many commodity-based industries in both developed and developing countries. Recent studies on the emergence of a high-end fashion sector in India (Khaire, 2014), or the emergence of the microbrewery movement in the U.S. (Carroll and Swaminathan, 2000) provide compelling examples of these dynamics, which generate economic value by producing symbolic content that connects creative individuals with multiple audiences. A better understanding of the interconnected issues of commensuration, authenticity, ordering, and comprehensibility as conditions for the emergence of creative genres within commodity-based industries is 
necessary for unleashing the creative potential tied up in many commodity-based mass-market configurations between producers and consumers. 


\section{REFERENCES}

Australian Bureau of Statistics (2012). Australian Wine and Grape Industry. Catalog 1329.0.55.002. Available at:

http://www.abs.gov.au/AUSSTATS/abs@.nsf/DetailsPage/1329.0.55.0022011-

12?OpenDocument

Anderson, K. and Nelgen, S. (2011). Global Wine Markets, 1961-2009: A Statistical Compendium. Adelaide: University of Adelaide Press

The Australian and New Zealand Wine Industry Directory (2014). Extracts available at: http://www.winebiz.com.au/statistics/industrybodies.asp

Aylward, D. (2004). Working together: innovation and export links within highly developed and embryonic wine clusters. Strategic change, 13(8), 429-439

Aylward, D. (2006). Innovation lock-in: unlocking research and development path dependency in the Australian wine industry. Strategic Change, 15(7-8), 361-372

Aylward, D. and Turpin, T. (2003). New Wine in Old Bottles: A Case Study of Innovation Territories in "New World" Wine Production. International Journal of Innovation Management, 7(4), 501-525

Alvarez, J. L., Mazza, C., Strandgaard Pedersen, J., and Svejenova, S. (2005). Shielding Idiosyncrasy from Isomorphic Pressures: Towards Optimal Distinctiveness in European Film Making. Organization, 12(6), 863-888

Anand, N. and Croidieu, G. (in press). Niches, genres, and classifications in the creative industries, in Handbook of Creative Industries. Oxford: Oxford University Press Anand, N. and Peterson, R. A. (2000). When Market Information Constitutes Field: Sensemaking of Markets in the Commercial Music Industry. Organization Science, 11(3), $270-84$ 
Baron, J. N. (2004). Employing identities in organizational ecology. Industrial and Corporate

Change, 13, 3-32

Becker, H. S. (1982). Arts Worlds. Berkeley: University of California Press

Beverland, M. (2006). The Real thing: Branding authenticity in the luxury wine trade. Journal of Business Research, 59(5), 251-258

Bourdieu, P. (1984). Homo Academicus. Paris: Les Editions de Minuit

Byron, R P and Ashenfelter, O. (1995). Predicting the Quality of an Unborn Grange, The

Economic Record, The Economic Society of Australia, 71(212), 40-53

Carroll, G. R. and Swaminathan, A. (2000). Why the Microbrewery Movement?

Organizational Dynamics of Resource Partitioning in the U.S. Brewing Industry. American Journal of Sociology, 106(3), 715-62

Carroll, G. R. and Wheaton, D. R. (2009). The Organizational Construction of Authenticity: An Examination of Contemporary Food and Dining in the U.S.. Research in Organizational Behavior, 29: 255-282

Chauvin, P. M. (2010). La Signature Enologique. Frontières et Transferts de Réputation sur le Marché des Consultants Bordelais. Sociologie du Travail, 4(52): 461-479

Clarke, O. (2004). Australian wine companion. Harvest Books

DiMaggio, P. J. (1991). Constructing an Organizational Field as a Professional Project: U.S. Art Museums, 1920-1940. In P. DiMaggio and W. W. Powell (Eds) The New Institutionalism in Organizational Analysis, University of Chicago Press, 267-292.

Douglas, M. (1986). How Institutions Think. Syracuse, NY: Syracuse University Press

Dunphy, R. and Lockshin, L. (1998). The evolution of the Australian wine show system. Wine Industry Journal, 13(4), 395-402

Ennis, P. H. (1992). The Seventh Stream: The Emergence of Rocknroll. Hanover, NH:

Wesleyan University Press 
Espeland, W. and Stevens, M. (1998). Commensuration as a Social Process. Annual Review of Sociology, 24, 313-343

Etzion, D. and Ferraro, F. (2010). The Role of Analogy in the Institutionalization of Sustainability Reporting. Organization Science, 21(5), 1092-1107

Hirsch, P. (2000). Culture industries revisited. Organization Science, 11(3), 199-202

Hooke, H. (1994). Max Schubert: Winemaker. Kerr Publishing

Hsu, G. (2006). Jacks of All Trades and Masters of None: Audiences' Reactions to Spanning Genres in Feature Film Production. Administrative Science Quarterly, 51(3): 420-450

Johnson, H. (1989). Histoire mondiale du vin. Paris: Hachette

Karpik, L. (2007). L'Economie des Singularités. Paris: Gallimard

Khaire, M. (2014). Fashioning an Industry: Socio-cognitive Processes in the Construction of Worth of a New Industry. Organization Studies, 35 (1), 41-74

Khaire, M., and Wadhwani, R. D. (2010). Changing Landscapes: The Construction of Meaning and Value in A New Market Category. Modern Indian Art. Academy of Management Journal, 3(6), 281-1304

Lamont, M. and Molnar, V. (2002). The Study of Boundaries in the Social Sciences. Annual Review of Sociology, 28,167-195

Lampel, J. and Shamsie, J. (2000). Critical Push: Strategies for Creating Momentum in the Motion Picture Industry. Journal of Management, 26(2): 233-257

Lena, J.C. (2012). Banding Together: How Communities Create Genres in Popular Music. Princeton: Princeton University Press

Lena, J. C., and Peterson, R. A. (2008). Types and Trajectories of Music Genres. Review Literature And Arts Of The Americas, 73, 697-718

Osmond, R. and Anderson, K. (1998). Trends and cycles in the Australian wine industry, 1850 to 2000. Adelaide: Center for International Economic Studies, University of Adelaide 
Pachucki, M. A., Pendergrass, S. and Lamont, M. (2007). Boundary Processes: Recent Theoretical Developments and New Contributions. Poetics, 35(6), 331-351

Peterson, R. A. (1990). Why 1955? Explaining the Advent of Rock Music. Popular Music, $9(1), 97-116$

Peterson, R. A. (2005). In Search of Authenticity. Journal of Management Studies, 42(5), $1083-1098$

Peterson, R. A., and Anand, N. (2004). The Production of Culture Perspective. Annual Review of Sociology, 30(1), 311-334

Peterson, R. A. and Berger, D. C. (1975). Cycles in symbol production: the case of popular music. American Sociological Review, 40, 158-73

Rao, H., Monin, P. and Durand, R. (2003). Institutional Change in Toque Ville: Nouvelle Cuisine as an Identity Movement in French Gastronomy. American Journal of Sociology, 108(4): 795-843

Roberts, B. P. W., Khaire, M., and Rider, C. I. (2011). Isolating the Symbolic Implications of Employee Mobility : Price Increases after Hiring Winemakers from Prominent Wineries. American Economic Review, 101(3): 147-151

Robinson, J. (2006). The Oxford companion to wine. 3rd ed. Oxford: Oxford University Press Suchman, M. C. (1995). Managing Legitimacy: Strategies and Institutional Approaches. Academy of Management Review, 20(3), 571-610

Tefler, D. J. (2001). Strategic Alliances along the Niagara Wine Route. Tourism Management, 22(1), 21-30.

Ventresca, M. and Mohr, J. (2002). Archival Research Methods. Blackwell Companion to Organizations. In Baum, J A C., (ed.) The Blackwell Companion to Organizations. WileyBlackwell, 805-828 
White, H.C. and White, C.A. (1965). Canvases and Careers: Institutional Change in the French Painting World. New York, NY: Wiley

Winemakers' Federation of Australia (1996). Strategy 2025: The Australian Wine Industry. Adelaide: Australian Wine Foundation Publications 
TABLES AND FIGURES

\begin{tabular}{|c|c|c|c|c|c|c|}
\hline & \multicolumn{6}{|c|}{ Time period } \\
\hline & 1950-59 & 1960-69 & 1970-79 & 1980-89 & 1990-99 & $2000-09$ \\
\hline Average annual wine production ('000 liters) & $\mathbf{n} / \mathbf{a}$ & 167,500 & 227,992 & $\mathbf{3 3 4 , 5 8 7}$ & 486,311 & $1,238,736$ \\
\hline Of which table wine ('000 1) & 24,757 & 48,247 & 161,824 & 271,498 & 449,133 & $\mathrm{n} / \mathrm{a}$ \\
\hline Share of table wine in total wine production $(\%)$ & $\mathrm{n} / \mathrm{a}$ & 28.8 & 70.9 & 81.1 & 92.3 & $\mathrm{n} / \mathrm{a}$ \\
\hline Average annual wine-grape crush ('000 tons) & 127 & 185 & 433 & 516 & 691 & 1625 \\
\hline Of which premium-grape varieties ('000 t) & 19 & 32 & 137 & 212 & 416 & $\mathrm{n} / \mathrm{a}$ \\
\hline Share of premium-grape crush (\%) & 14.9 & 17.3 & 31.6 & 41.1 & 60.2 & $\mathrm{n} / \mathrm{a}$ \\
\hline Average annual domestic wine consumption ('000 liters) & $\mathbf{n} / \mathbf{a}$ & 69,000 & 161,000 & 312,000 & 323,000 & 436,000 \\
\hline Average annual domestic wine consumption per capita (l) & $\mathrm{n} / \mathrm{a}$ & 6 & 12 & 20 & 18 & 21 \\
\hline Average annual wine exports ('000 liters) & $\mathbf{n} / \mathbf{a}$ & 9,000 & 7,000 & 18,000 & 195,000 & 606,000 \\
\hline Value of avg. annual wine exports ('000 USD [current]) & $\mathrm{n} / \mathrm{a}$ & 4,000 & 6,000 & 31,000 & 371,000 & $1,728,000$ \\
\hline Share in value of global wine export (\%) & $\mathrm{n} / \mathrm{a}$ & 0.6 & 0.3 & 0.5 & 3.4 & 8.5 \\
\hline Creation of wineries (total during time period) & & & 199 & 365 & 1023 & $\mathbf{n} / \mathbf{a}$ \\
\hline
\end{tabular}

${ }^{a}$ Wineries created between 1950 and 1969.

Data sources: Anderson and Nelgen (2011); Australian Bureau of Statistics (2012); Osmond and Anderson (1998); The Australian and New Zealand Wine Directory (2014).

Table 1

Australian Wine Industry and Fine-Wine Development 


\begin{tabular}{ll}
\hline $\begin{array}{l}\text { Second-order } \\
\text { themes }\end{array}$ & Representative quotes \\
\hline
\end{tabular}

Honors from industryregulating institutions

Rankings by experts and critics

Economic distinctions

References to prestigious industry producers

Practices resonant of established art worlds

Establishment of a cultural experience

Echo of national history/identity

Anchor of national pride

The creator as representation of the industry

Personification of cultural products
"Bottles of 1990 Penfolds Grange were auctioned last December for \$420, while the 1994 vintage, released last year, sells for up to \$300." (The Sydney Morning Herald, 2000)

"The iconic 1990 Grange was voted wine of the year by the influential US magazine Wine Spectator. The 1998 Grange also achieved cult status, with Wine Spectator and US critic Robert Parker scoring it at 99 points out of 100." (The Sydney Morning Herald, 2006)

"By pricing the legendary Grange Hermitage (now simply called Grange) at an insulting $\$ 130$ a bottle, Australia's best winery, Penfolds, has sinned. Now it thinks it can apologize by launching a bevy of new releases priced between $\$ 9$ and \$22. Apology accepted. The new wines are simply extraordinary." (The Washington Post, 1997)

"Currently, Grange Hermitage is one of Australia's most prized collectibles. Since production is rarely more than 6,000 cases a year, the competition for both new and old bottles is fierce among the militantly chauvinistic Australians. Recently, older bottles have sold there for the equivalent of $\$ 2,000$, and Grange collectors are recognized as a national phenomenon." (The New York Times, 1989)

"Penfold's Grange Hermitage, born in 1952, is made from the Shiraz or Syrah grape, by a living legend, Max Schubert. He introduced the practice of ageing red wine in new 226-litre oak casks to Australian winemaking after learning it in Bordeaux, France." (The Sydney Morning Herald, 1990)

"During an extensive tour of the Bordeaux region of France in 1950, Max Schubert studied numerous wine-making practices that have now become an integral part of Penfolds' winemaking technique. He also observed the practice of maturing wine in new oak casks, a method previously untried in Australia." (1976 Grange bottle label)

"Oprah served Grange on her final episode of The Oprah Winfrey Show, with a guest appearance by Australian actor Hugh Jackman in front of thousands of fans on the Sydney Opera House stage." (www.liffordwineagency.com, 2011)

"Right now, connoisseurs around Australia are psyching up for the seven-course gastronomic extravaganza, The Penfolds-Hilton International Ultimate Dinner 1986 ... The menu has been matched with 10 wines from Penfolds including ... museum stock 1971, 1966 and 1955 Grange ..." (The Sydney Morning Herald, 1986)

"Penfolds swept the board in a recent blind tasting of more than 40 shiraz wines from Australia for the British Wine magazine. Grange Hermitage was far and away the top scorer." (The Sunday Times, 1988)

"[A]s the second half of the twentieth century hurried into the last few decades, it became clear that what Australia did have was personalities determined to impose their wills and ways upon wine. People who were gritty, determined, focused, passionate, imaginative and opinionated. Shy, retiring and conciliating? No. Never. What would that have achieved in God's Own Country, where sometimes the only motto worth knowing is 'You gotta have a go'. And have a go they did." (Clarke, 2004, p. 30)

"Australia's reputation as a wine country was built by personalities. Other countries build their reputation on the places where the grapes grow." (Clarke, 2004, p. 30)

"The National Trust of South Australia, which usually concerns itself with monumental solids, not transitory liquids, has declared Grange an item of such significance and originality that it should be recognized, celebrated and protected for present and future generations." (The Sunday Times, 2001)

"Grange was considered as the leader of the "Australian fine wine revolution'." (Johnson, 2000)

"When Max Schubert created Grange in 1951, he changed the course of Australian winemaking history." (The Sydney Morning Herald, 2006)

"During an extensive tour of the Bordeaux region of France in 1950, Max Schubert studied numerous wine-making practices that have now become an integral part of Penfolds' winemaking technique. He also observed the practice of maturing wine in new oak casks, a method previously untried in Australia." (1976 Grange bottle label)

"Winemaker Stephen Henschke and his viticulturist wife, Prue, are internationally renowned not just for the Hill of Grace shiraz, which Henschke's father first produced in 1958, but also for their innovative viticultural practices and research." (The Sydney Morning Herald, 2010)

"The techniques employed in the research and development of Penfolds' wines are astonishing. Max Schubert and his team pioneered: major advances in yeast technology and paper chromatography; the understanding and use of $\mathrm{pH}$ in controlling bacterial spoilage; the use of headed down/submerged cap fermentation and the technique of rack and return cold fermentation practices; the use of American oak as a maturation vessel and perhaps most critically - partial barrel fermentation. The Penfolds Wine Making Philosophy is the accumulation of more than half-a-century of knowledge and winemaking practice initiated by Max Schubert and subsequently refined by Don Ditter, John Duval and Peter Gago." (www.langtons.com.au)

\section{Table 2}

\section{Representative Quotes for Second-Order Themes}




\begin{tabular}{|c|c|c|c|c|c|}
\hline & & \multicolumn{4}{|c|}{ Empirical Mechanisms in Australian Fine Wine } \\
\hline & & $\begin{array}{l}\text { Shifting and Layering of } \\
\text { Metrics }\end{array}$ & $\begin{array}{l}\text { Analogies with } \\
\text { Creative Industries } \\
\text { and Practices }\end{array}$ & $\begin{array}{l}\text { Resonance with } \\
\text { Society-level } \\
\text { Logics } \\
\end{array}$ & Personification \\
\hline \multirow{4}{*}{ 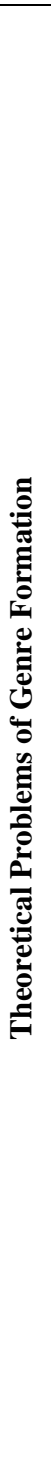 } & Commensuration & $\begin{array}{l}* 1960 \text { s/70s: Wine-show medals } \\
\text { allow comparison of wines in } \\
\text { different competition } \\
\text { categories, and a large } \\
\text { definition of genre in Australia } \\
* 1970 \text { s/80s: Critics' rankings } \\
\text { allow for international wine } \\
\text { comparison }(90+\text { points on } \\
\text { Parker's scale) } \\
* 1990 \text { s: Auction prices allow } \\
\text { for comparison beyond wine } \\
\text { (e.g. paintings) }\end{array}$ & $\begin{array}{l}\text { Differences among wines } \\
\text { within the genre are } \\
\text { expressed by referring to } \\
\text { different prestigious } \\
\text { regions (e.g., Bordeaux } \\
\text { versus Rhône valley) }\end{array}$ & & \\
\hline & Authenticity & $\begin{array}{l}\text { Metrics reinforce and actualize } \\
\text { genre rules over time }\end{array}$ & & & $\begin{array}{l}\text { Highly exposed } \\
\text { individuals } \\
\text { contribute to } \\
\text { defining the rules of } \\
\text { the genre }\end{array}$ \\
\hline & Ordering & $\begin{array}{l}\text { *Medals, rankings, and prices } \\
\text { establish a rank order of more } \\
\text { or less prestigious wines within } \\
\text { the fine-wine genre } \\
\text { *Non-members of the genres } \\
\text { are not concerned by the } \\
\text { metrics (e.g., they do not } \\
\text { appear in Langton's } \\
\text { classification) }\end{array}$ & & & \\
\hline & Comprehensibility & $\begin{array}{l}* 1960 \text { s/70s: Wine-show medals } \\
\text { single out wines that meet } \\
\text { objectified quality criteria (best } \\
\text { wine) } \\
\text { *1970s/80s: Critics and media } \\
\text { define the genre (90-point } \\
\text { wine) } \\
\text { *1990s: Auction houses } \\
\text { regroup wines that resemble } \\
\text { each other (wine as an } \\
\text { artistic/collectible good) (most } \\
\text { expensive, most famous wine) }\end{array}$ & $\begin{array}{l}\text { *Analogies with other } \\
\text { prestigious wine regions } \\
\text { (e.g., Bordeaux) function } \\
\text { as programmatic } \\
\text { statements } \\
\text { *Actors and practices } \\
\text { normally associated with } \\
\text { the arts-and-culture field } \\
\text { (critics, collectors, } \\
\text { auctions, and curatorship) } \\
\text { signal a departure from } \\
\text { everyday consumption } \\
\text { practices }\end{array}$ & $\begin{array}{l}\text { *Resonance with } \\
\text { overarching societal } \\
\text { logic (tradition, } \\
\text { roots, outback, etc.) } \\
\text { enables the } \\
\text { construction of a } \\
\text { sense of historical } \\
\text { truth in the wines } \\
\text { (the idea of a lost } \\
\text { paradise) } \\
\text { *Emphasis on } \\
\text { Australian traditions } \\
\text { allows the claiming } \\
\text { of a particular and } \\
\text { recognizable } \\
\text { Australian wine } \\
\text { style }\end{array}$ & \\
\hline
\end{tabular}

Table 3

Issues of Boundary Formation and Mechanisms of Genre Emergence 


\begin{tabular}{l}
\hline 'Refinement of wine shows' evaluation system towards rigorous quality \\
'Creation of wine show medals and trophies \\
\hline \hline 'Emergence and development of wine critics and joumalists \\
"Creation of joumal rankings, shaping order between wines in terms of \\
quality \\
\hline \hline 'Emergence and development of wine suctions by suction houses \\
'Grange as a great collectsble, at very high prices \\
'Establishment of wine collectors, for whom wine is a financial investment
\end{tabular}

\begin{tabular}{|c|c|c|}
\hline $\begin{array}{l}\text { "Australian fine wines positioned within the global wine circuit } \\
\text { "French Bordesux influences Australian fine wines }\end{array}$ & $\begin{array}{l}\text { References to prestigious and } \\
\text { symbolic industry producers }\end{array}$ & $\begin{array}{l}\text { Analogies } \\
\text { with }\end{array}$ \\
\hline $\begin{array}{l}\text { "Penfolds organizes curatorship through recorking clinics } \\
\text { "Comparison of fine wines with other creative industries such sa haute } \\
\text { cuisine }\end{array}$ & $\begin{array}{l}\text { Practices res onant of established } \\
\text { art worlds }\end{array}$ & $\begin{array}{l}\text { established } \\
\text { creative } \\
\text { industries }\end{array}$ \\
\hline $\begin{array}{l}\text { "Grange present at prestigious wines and haute cuisine } \\
\text { "Emergence and development of tastings }\end{array}$ & $\begin{array}{l}\text { Reference to a cultural } \\
\text { experience }\end{array}$ & $\begin{array}{l}\text { and } \\
\text { practices }\end{array}$ \\
\hline
\end{tabular}

\begin{tabular}{|c|c|c|}
\hline $\begin{array}{l}\text { "Creation of several wine-related institutions at the national level } \\
{ }^{*} \text { Max Schubert embodies the nation-building and entrepreneurial spirit } \\
\text { "Evolution of consumer tastes towards quality wines }\end{array}$ & $\begin{array}{l}\text { Echo of the national history and } \\
\text { identity }\end{array}$ & \multirow{2}{*}{$\begin{array}{l}\text { Resonance } \\
\text { with } \\
\text { society- } \\
\text { level logics }\end{array}$} \\
\hline $\begin{array}{l}\text {-Grange recognized as a Heritage Icon of South Australia } \\
\text { *Grange as an intemational symbol of the uniqueness of Australian wines }\end{array}$ & Anchor of national pride & \\
\hline $\begin{array}{l}\text { "Max Schubert as a reference for the evolution of Australian wine industry } \\
\text { "Awards dedicated to winemakers are created }\end{array}$ & \multirow{2}{*}{$\begin{array}{l}\text { Creative individuals as } \\
\text { representatives of the industry } \\
\text { and genre }\end{array}$} & \\
\hline "Winemakers are presented as "the public face" of wine producers & & \multirow{2}{*}{$\begin{array}{l}\text { Personifica } \\
\text { tion }\end{array}$} \\
\hline $\begin{array}{l}\text { * Signature on wine bottles is highly valuad by the market } \\
\text { *Critics talk about winemakers and associated their names to wines }\end{array}$ & $\begin{array}{l}\text { Creative individual authorship of } \\
\text { a cultural product }\end{array}$ & \\
\hline
\end{tabular}

Figure 1

Data Structure 


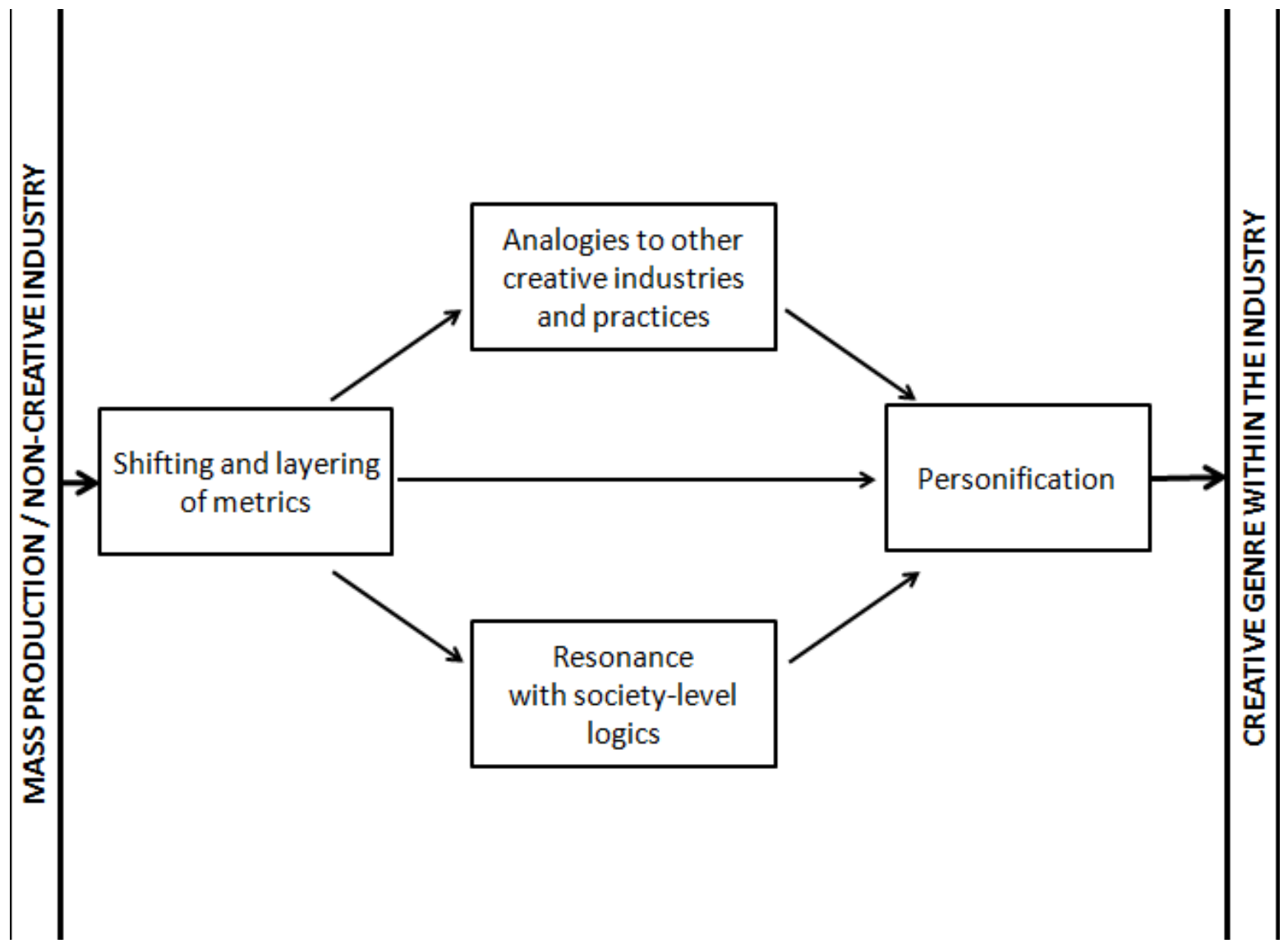

Figure 2

Process Model of Genre Emergence 